Article

\title{
The Fog of Extremism: Governance, Identity, and Minstrels of Exclusion
}

\author{
Amyn B. Sajoo \\ Simon Fraser University, Faculty of Arts \& Social Sciences, Vancouver, BC V6B 5K3, Canada; E-Mail: asajoo@sfu.ca
}

Submitted: 22 December 2015 | Accepted: 11 February 2016 | Published: 19 April 2016

\begin{abstract}
An insistent focus on extremism and radicalization with regard to current Islamist trends masks the failures of pluralist citizenship, amid a larger crisis of identity. Whether in Muslim-majority societies or in the Euro-North American diaspora, "Islam" and "politics" are touted as explaining patterns of severe violence by state/non-state actors. Neither category accounts more than superficially for the complexities at hand, which revolve around exclusionary models of identity, faith and civil society. Successful narratives of inclusive citizenship depend on key markers outside of modernist secular orthodoxy. Theologies of inclusion are vital in fostering pluralist civic identities, mindful of the ascendance of puritanical-legalist theologies of exclusion as a salient facet of public cultures. Multiple surveys reveal the depth of exclusivist conservatism in diverse Muslim societies. These stances not only undermine civil society as a locus for engendering pluralist identities, but also undergird the militant trends that dominate the headlines. Targeting militants is often essential-yet is frequently accompanied by the willful alienation of Muslim citizens even within liberal democracies, and a growing "official" sectarianism among Muslim-majority polities. Convergent pluralisms of faith and civic identity are a vital antidote to the fog that obscures the roots as well as the implications of today's extremist trends.
\end{abstract}

\section{Keywords}

citizenship; civil society; exclusion; human rights; Islam; minorities; pluralism; radicalization; secularism; sectarianism; sharia; theology

\section{Issue}

This article is part of the issue "Religious Diversity and Social Inclusion", edited by Gary Bouma (Monash University, Australia).

(C) 2016 by the author; licensee Cogitatio (Lisbon, Portugal). This article is licensed under a Creative Commons Attribution 4.0 International License (CC BY).

The Balkan minstrels continued to tell their tales, now interrupting each other. In their desire to be accepted they had forgotten the insults, and humbly, almost awkwardly, begged: We want to be like you. We think like you. Don't drive us away. The old lady sensed that there was something missing from their tales.

'Could you sing the things you have been telling us?' she asked.

They were shaken as if they had been dealt a blow. Then, tearing themselves out of their stupor, one after the other, each in his own language, and finally in Latin, said 'No.' Non.

'Why not?' she asked kindly.

'Non, domina magna, we cannot under any circumstances. We are minstrels of war.'
They could not break out of the mold. Besides which, they would first have to consult their elders. Consult the dead...Non.

Ismail Kadare, Elegy for Kosovo, 1998

\section{Introduction}

For well over a decade-in the wake of the events of September 11, 2001, and most notably the US-led "war on terror"-responses to Islamist trends have been marked by an avowed focus on "extremism." A rising concomitant is the targeting of "radicalization" through legislation and social policy. Indeed, the latter is deemed a longer term and more subtle facet of the strategic response to Islamism, and to militant groups in particular. "We are engaged in a struggle that is 
fought on many fronts and in many forms," explains the United Kingdom home secretary, Theresa May, about a counter-terror law that includes banning "extremist" speakers from universities. "The threat we face right now is perhaps greater than it ever has been. We must have the powers we need to defend ourselves" (UK Government, 2014). This was echoed in France's response to the November 2015 terror attacks in Paris, where the language of "war" against a foreign "army" (Daesh/Islamic State) was coupled with an extended state of emergency allowing for special police powers, and constitutional changes relating to citizenship. ${ }^{1}$ An embattled "we" is engaged in nothing more, or less, than self-defense against the depredations of radicals - the very sentiments that drove the expansive post-September 11 vision of mortal combat against global terror, and the war in Iraq.

What is new about this ominous threat that will engage us indefinitely? Terms such as "cosmic" and "irrational" are commonly associated with the professed religiosity of the extremists and radicals that threaten our wellbeing (Juergensmeyer, 2003; Neumayer \& Plumper, 2009; Wilson, 2012). Whether in Muslimmajority societies or in the Euro-American diaspora, "Islam" or "politics" is touted as an explanatory category for patterns of severe violence by non-state actors. For some-scholars, politicians, journalists-it is not merely religion but Islam in particular that accounts for a sui generis propensity to violence. Orientalist tropes abound here, blithely oblivious or in spite of the trenchant critiques of that tradition offered up by Edward Said and others. For others, the explanations are about politics: in a secular age that demands sensitivity to scapegoating and persecution, Islam and Muslims are foils for struggles that are about perceptions of justice and the failure of democratic avenues of expression. To the extent that religion is a significant factor in radicalism and militancy, it is confined to extremist quarters that can be contained if not eradicated.

This article argues that neither category provides a tenable explanation, for all the historical and scientific rhetoric that is proffered in the guise of erudite critique. A binary view fails to account for a larger identity crisis that provides the setting for current Islamist trends, militant and otherwise. In a context where church and state find themselves in a complex relationship that does not fit the more familiar modelsAmerican, French, Saudi Arabian-religion no longer occupies the tidy institutional place that modernity assigned it in our individual and collective trajectories. Narratives of citizenship ignore this shift at their peril, if wedded to secularist claims about civic identities. Progressive theologies can play a vital role through in-

\footnotetext{
${ }^{1}$ Schofield (2015). The political and ethical perils of the "war metaphor" were promptly raised by The Economist-Prospero (2015).
}

clusive discourse and action. As David Santillana observed nearly a century ago in this regard, "every question of law is also a matter of conscience, and jurisprudence is based on theology in the final analysis" (1926, p. 5). Today, puritanical-legalist stances on the shari'a are a prime basis for exclusive and repressive orthodoxies: multiple surveys reveal the depth of conservatism on matters of faith and civic culture among ordinary Muslims. These stances nurture the extremism that dominates the headlines, and undermine civil society as the locus of pluralist identities. Military and policy responses to actors such as al-Qaeda, Daesh ("Islamic State"), Boko Haram and al-Shabab are necessary. Yet strategic alliances are rife with and among governments that actively promote or shield antipluralist actors. And a deeper malaise of pluralist citizenship within the western diaspora is obscured in the war on extremism.

Without an ethos that takes seriously not only public religion but minority traditions in particular, secular frameworks of inclusion fall seriously short on effective citizenship. Our primary focus here is on the nexus of Islamist extremism and the larger malaise of identity in a globalized, secular modernity. Insecure identities seek shelter in a social and intellectual conservatism that may be religious and sectarian, but also secular, as in the case of nationalism. Examples of such trends in non-Muslim contexts are offered, though an elaborate survey is quite beyond the scope of this paper. I will first set forth the dichotomous claims about framing the militancy of actors that are deemed extremist in terms of "Islam" and "politics" as exclusive categories, before venturing into the underlying tensions of identity that find expression in religious conservatism and radicalization. Finally, I will address the ensuing challenges of pluralist citizenship that require an ethos of secular and religious inclusion-where material incentives are a necessary but insufficient condition.

An elucidation here on terminology. "Islamism" is an unsatisfactory descriptor of Muslim political action: it signals attachment to a faith tradition regardless of whether this actually has any merit. We do not standardly use such loose tags for political Judaism, Hinduism, Buddhism or Christianity. Nevertheless, "Islamism" has become a term of art in academic and media commentary (Martin \& Barzegar, 2010). I use it in the sense of a drive to foster "an ideological community," one that strives for state governance through official "moral codes in Muslim societies and communities" (Bayat, 2013, p. 4). Such drives may be expressed in national and transnational movements-from alMourabitoun, Boko Haram, al-Shabab and the Taliban, to al-Qaeda and Daesh. ${ }^{2}$ Islamists are distinguished

\footnotetext{
2 The term "Daesh" is used throughout this paper, as the appropriate acronym for al-Dawla al-Islamiya al-Iraq al-Sham (Islamic State of Iraq and the Levant) (Grayling, 2016). This is also
} 
from non-political actors that advocate for spiritual or social welfare goals, and also "active pietist" groups that aspire to shape civil-political identities. The term jihadi, which tends to invoke a religiously-inspired struggle against "wordly" targets, including Muslim ones perceived as slack in their commitment to Islam, is highly diffuse; active pietists and civic movements may profess jihad as much as do militants (Abu-Rabi, 2010; Stephan, 2009). Many Islamists do not espouse militancy at all; some prefer the electoral route where available, as with prominent Egyptian and Tunisian and political actors in the "Arab Spring." Here, "militancy" and "extremism" refer to Islamist choices on this score, the acceptance of which is about "radicalization." The choices may be strategic or theological, informed or otherwise; it is our task to seek to understand why these choices are acted upon.

\section{Framing Extremist Militancy}

\section{1. "Islam Is the Answer"}

For an array of commentators, the self-proclaimed religiosity of actors who resort to violence suffices as the rationale for their choices. "Islam" accounts for a spectrum of motivations and realities that are summed up under the rubrics of extremism and radicalization, which characterize militancy ranging from that of major non-state groups to freelance terrorists. At its simplest, this equates the most aggressive forms of political Islam, or "Islamism," with Islam as a faith tradition. Typical are the post-September 11 writings of Bruce Bawer (2006, 2009), Gisele Littman (2005), Mark Steyn (2006), and Robert Spencer (2008, 2009). Populist in language, style and reach (many have been bestsellers), they perceive an "Islamified Europe" as the ultimate outcome of the mere existence of Muslim migrants-because "Islam itself is a political project," to quote Steyn. Muslim values, then, are not only incompatible with those of a Judeo-Christian West, but are ultimately ideological more than anything else. Indeed, the entirety of Muslim history and civilization are reduced-especially in the work of Spencer-to a linear narrative of animus against non-Muslims.

These populist writings, for all their tenuousness, have the benefit of an enabling analytical landscape. A key node is the "clash of civilizations" posited by Samuel Huntington (1996): an account of "Islamic culture" as a singular entity in perpetual conflict with western values, a teleology which Muslims fit into no matter where they are located. "The underlying problem for the West is not Islamic fundamentalism," according to Huntington, but rather "Islam, a different civilisation whose people are convinced of the superiority of their

the term used by the UN with regard to Syria, as in Resolution 2254 (2015, December, 18), adopted by the UN Security Council. culture and are obsessed with the inferiority of their power" (1996, pp. 217-218). Although a plethora of critiques have undercut virtually all the serious claims in this account, ${ }^{3}$ it remains influential after the events of September 11. Populist discourse draws on its sweeping assumptions and projections, stoking public fears about migration, Muslim minorities and national security (Abrahamian, 2003; M. Dunn, 2006; Wright, 2015). Then there is the work of scholars such as Daniel Pipes (2002a), Niall Ferguson (2004, 2006, 2011), and Bernard Lewis (1990, 2002, 2003), who have weighed in with insights on the histories of the Middle East/Islam, and the implications for western societies. Many of these insights are essentialist in casting Muslims and Islam as a unitary vector separate from and threatening to the stability and wellbeing of western societies.

Even for an eminent historian of the Middle East such as Lewis, "Islam" serves as a discrete category that ultimately trumps the diverse politics, economics and cultures of Muslim societies past and present. His tone is more temperate than Huntington's. Yet the same teleology is voiced, wherein western societies find themselves in the path of a "Muslim rage" that drives contemporary conflicts. Thus: "Islam, like other religions, has also known periods when it inspired in some of its followers a mood of hatred and violence. It is our misfortune that part, though by no means all or even most, of the Muslim world is now going through such a period, and that much, though again not all, of that hatred is directed against us" (Lewis, 1990). But he can be cavalier, as in his oft-cited 2004 proclamation to a German newspaper that "Europe will have a Muslim majority by the end of the twenty-first century at the very latest...Europe will be part of the Arab west-the Maghreb." (Schwanitz, 2004). ${ }^{4}$ Demographics in this context is, of course, a charged subject with farreaching implications for perceptions of identity as well as security. And this is reflected in western academic and populist commentary on extremist militancy and social radicalization.

At the most mundane level of linkage between religious identity and anti-western animus, Pipes pulls no punches: "A vast number of Muslims, those living in the Europe and the Americas no less than elsewhere, harbor an intense hostility to the West. For most Muslims, this mix of envy and resentment remains a latent sentiment, but for some it acquires operational significance" (2002b). Just as forthright is the Harvard scholar Niall Ferguson, no specialist on the Middle East or the Muslim world, but an authority on global history. "The greatest of all strengths of radical Islam...is that it has demography on its side. The western culture against

\footnotetext{
${ }^{3}$ Edward Said (2001) labelled it as being about "a clash of ignorance" in which "the West" and "Islam" are analytically poor banners.

${ }^{4}$ A claim challenged by The Economist (2006).
} 
which it has declared holy war cannot possibly match the capacity of traditional Muslim societies when it comes to reproduction" (2006). Apart from the intriguing claim that demography is a greater weapon than ideas or anything else in the extremist arsenal, it is worth noting the leap in reasoning from "radical Islam" to "traditional Muslim societies." Furthermore: "A youthful Muslim society to the south and east of the Mediterranean is poised to colonize-the term is not too strong-a senescent Europe...A creeping Islamicization of a decadent Christendom is one conceivable result: while the old Europeans get even older and their religious faith weaker, the Muslim colonies within their cities get larger and more overt in their religious observance" (Ferguson, 2004).

Bruce Bawer is almost regretful about the inexorable nature of this linkage, and the defensive impulse of its victims. "Many European Muslims," he asserts in his acclaimed While Europe Slept: How Radical Islam is Destroying Europe From Within, "may themselves be moderates, yet may have a concept of religious identity that makes it difficult for them to side with infidels against even the most violent of their fellow Muslims" (2006, p. 229). Evidence of this may heavily be to the contrary, judging by the volume of diasporic Muslim denunciation of acts of terrorism by fellow Muslims, ${ }^{5}$ and the data on migrant integration and marginalization (Saunders, 2012). Yet if one accepts the premise that religious identity for Muslims is an undifferentiated whole-leaving scant room for distinction between a member of Daesh or al-Qaeda and a Muslim member of Amnesty International or Médecins Sans Frontières-then the apprehensions of Bawer, Lewis, Ferguson, and Pipes are warranted. Indeed, the premise was explicitly invoked by Anders Breivik, the Norwegian whose manifesto justifying his 2011 acts of mass terror repeatedly cited the writings of Bawer, among other influences (Breivik, 2011; see more generally Townsend \& Traynor, 2011).

Those sentiments frequently lament the erosion of Europe's Christian identity, as a bastion against Islam and Muslims. How ironic, then, that the wider modernist discourse, even in much of the Muslim world, is about secularism as serving as a bastion against religion at large. At its most assertive, this latter view strips secularism down to the absence of public and private religion-a state of affairs which is deemed rational and friendlier to nonviolence. For the cluster of

\footnotetext{
${ }^{5}$ This extends to repeatedly petitioning mainstream newsmedia to cease using the term "Islamic State" in describing the group widely called "Daesh" in the Muslim world-and a graphic social media campaign launched in 2014 against the group under the banner \#NotInMyName. See more generally Charles Kurzman's web-page, Islamic statements against terrorism. Retrieved from http://kurzman.unc.edu/islamicstatements-against-terrorism
}

"new atheists," such as Richard Dawkins, Daniel Dennett, Sam Harris, Christopher Hitchens, and Ayaan Hirsi Ali, the trends in post-September 11 extremism have much to do with religious belief (Kettell, 2013; Jacoby \& Yavuz, 2008). The intellectual integrity of this stance has been trenchantly challenged in assorted quarters, along with it ideological direction (Atran, 2010; Hedges, 2008; Ruse, 2010; Taylor, 2013). Suffice it to say that the new atheism plays into the politics of both the "clash of civilizations" and the demographic thesis, feeding public phobias about an invasive irrationality tied to Islam and Muslims. "We are at war with Islam," proclaims Sam Harris, "with precisely the vision of life that is prescribed to all Muslims in the Koran, and further elaborated in the literature of the hadith, which recounts the sayings and teachings of the Prophet" (2004, p. 110). A stronger reiteration of Huntington would be hard to find.

\section{2. "Politics Is the Answer"}

Secular globalization, argues the French sociologist Olivier Roy in Holy Ignorance, has snapped the premodern link between religion and culture. Religions today tend to regard culture as "profane, secular, or pagan" (2010, p. 28), which stakes a claim to authenticity by asserting a purity that renounces the political. But since politics, like culture, is everywhere, it is subsumed within faith traditions-thus sacralizing the world. For Roy, this is the ultimate counterpoint to modernity's secularization of the world, wherein everything that was once sacred is now subject to the appraisal of the economic, social and scientific. In the confrontation of faith and material culture, "holy ignorance" is rife: each side reimagines the other in its own image, a process that "is not contradicted by external social practice" (2010, p. 217). Roy's rich data is not merely about faith traditions resisting external social realities, but equally about the secular "formatting" of religious practices in public policy and corporate culture, with scant regard to the actual complexities of those practices.

The flipside of claiming that Islam explains extremist militancy and radicalism, then, is that hard political realities do so. A major strand of analysis aims to counter the secularist essentialism that frames religion, and Islam in particular. The cliché that "Islam is way of life" ends up signifying that everything is somehow about theology. Orientalism's long history of doing this is a matter of record, and the legacy remains with us (Said, 1997, 1994). Sami Zubaida's Beyond Islam offers a detailed account of Middle East modernity that strives to locate religion within economic and social contexts, pointedly rejecting the very idea of "Islamic society" so beloved of Orientalist narratives (2011). Instead, it is the "materiality of religion" in everyday lifeexpressed in "the shaping of political actors, alliances 
and conflicts" - that Zubaida holds up for appraisal, notably in premodern Ottoman and present day Egyptian, Iranian and Turkish societies (p. 78). The tangibility of this approach to understanding religion, along with its humanizing quality, stand in stark contrast to the exoticization and othering of Orientalist accounts. Further, the ciphers of oppositional "western" and "Islamic" societal values are exposed, with substantial sociological data about their shared and overlapping realities, past and present.

At the same time, such approaches can secularize faith-centred impulses and actions. What Said called the "political actualities" entailed by the trends that proclaim a "return to Islam," tend here to overwhelm and obscure the theological drives that are real features of the landscape (1997). This is not necessarily the intent-which, typically, is to offer a sober counternarrative to essentialist accounts. Thus in Doug Saunders' The Myth of the Muslim Tide: Do Immigrants Threaten the West, the reader is offered an impressive corpus of statistical and historical data that map the social pathways of migrants in Europe and North America, including Catholics and Jews (2012). The debunking of anti-immigrant and anti-Muslim claims is cogent and, in the present climate, laudable. Still, Saunders echoes the view that secularizing trends among Muslim migrants should reassure us-along with the growing "privatization of religion" in Muslim societies such as Egypt, Iran and Turkey. Social inclusion and social peace rest on the conformity of Muslims to a version of modernity that is familiarly secular.

Again, in response to the puritanical tendency to separate religion from public culture noted by Roy, there are official attempts at doing the reverse. Cultural categories, after all, are more amenable to secular analysis and management in public policy/lawmakingthe "formatting" of religion (2010, pp. 187-191). This is accentuated in settings where official secularism is hard-wired into the constitution, as in France and Belgium; but Roy's evidence extends far beyond. In the US, where religion is well integrated into political culture, as well as Saudi Arabia and Iran, where official orthodoxies prevail, minority practices must fit into the approved administrative formats. The growing diversification among religions worldwide, institutional and otherwise, intensifies the challenge of "managing" them via existing formats (Bouma, 2008; Juergensmeyer, Griego \& Soboslai, 2015). Moreover, new security regimes worldwide since the events of September 11, 2001, and the Edward Snowden revelations of 2013, have ushered in pervasive intrusions into group and individual domains (Lyon, 2015)-underscoring the need to format and control a range of "religious" behaviors, from piety and worship to socio-political activity. In a reminder of how surveillance schemes can violate the basic civil rights of religious groups, the US Court of Appeals rebuked New York City police for the arbitrary "classification" of Muslims along lines reminiscent of official abuses against African-Americans, Jews, and Japanese-Americans (Hassan vs. The City of New York, 2015).

For Will Kymlicka, a leading scholar of citizenship in diverse societies where Muslims live in diaspora communities, the emphasis has been on "cultural inclusion" as the gateway (2001; Kymlicka \& Norman, 2000); this is rationalized in terms of democratic and social justice, and the imperatives of civic education. Minority rights are likewise framed in terms of the complexities of ethnic politics and effective legalpolitical accommodation (Pföstl \& Kymlicka, 2015). Tariq Modood draws attention to the limits of such multicultural frameworks when it comes to religious minorities, calling for more effective forms of secularism to accommodate such citizens (2000). Being secular does not ipso facto mean being "value neutral;" secularism itself embodies a variety of value-postures on civic life (Berger, 1999; Bhargava, 1998; Martin, 2005). Recent literature has gradually taken this on board, as in Joshua Castellino and Kathleen Cavanaugh's seminal Minority Rights in the Middle East (2013), which is attentive to the dynamics of religious and socio-cultural identities in pursuit of equitable citizenship. It falls short, though, in engaging with the growing role of the shari'a with regard to the region's minorities, beyond normative statements (Sajoo, 2014). An incisive study of the Coptic minority in Egypt by Paola Pizzo explores the vital role of institutional faith actors on all sides in seeking both social and political inclusion-and importantly, links this to civil society (2015). There is a hint here of the evolving theologies of civic membership, though this remains unexplored.

The upshot is a thrust to frame the issues in political terms, at the expense of attention to theological components. Despite much criticism, the analytical vocabulary of human rights, minority claims, and social justice remains dominantly secular and secularizing. In significant part, this reflects frail public support even in liberal democratic societies for the accommodation of some religious expressions in the civic domain, especially when "multicultural tolerance" involves Muslims post-September 11 (Benton \& Nielsen, 2013; Wright, Johnston, Citrin, \& Soroka, 2016). Examples range from veiling to municipal zoning for mosques; a conspicuous display of civic resistance was the 2009 Swiss ban on minarets, after the results of a referendum that strongly overrode the official accommodationist stance (Cumming-Bruce, 2009). These public encounters with religion bring "sacred" laws and norms under the scrutiny of the political domain and can impart a strong sense of desacralization, if not secularization. Evidently, it is not only Islamists and their counterparts in other traditions who politicize their faith. Indeed, religious actors "struggle to come to terms with the very social 
landscape that the secular state was meant to address, namely the vast variation of identities housed within the borders of the nation" (Juergensmeyer et al., 2015, p. 32).

\section{Extremism, Faith and Identity}

\subsection{Modernity's Orphans}

Shortly after the arrest of Anders Breivik for the coldblooded slaughter of civilians on the Norwegian island of Utøya on July 22, 2011, there was consternation among the police over his main preoccupation. Amid fresh corpses and pools of blood, Breivik demanded attention for a tiny cut on his finger, from a splintered piece of a victim's skull. "Look, I'm hurt. This will have to be bandaged up...I can't afford to lose too much blood," he complained. Later in prison, Breivik bitterly grieved the failure to upgrade his game console from Playstation2 to Playstation3, and also the grip on his institutional rubber pen. He strutted like a bodybuilder for a prison photo. On the basis of psychiatric reviews, the court ruled that Breivik was not psychotic. Recounting at length the narcissism, lack of empathy, isolated childhood, and the screed (noted above) that voiced a hate-filled politics, Karl Knausgaard argues that these cannot fully explain why Breivik committed what has been called "the worst attack on Norwegian soil since the Second World War":

“Breivik's deed, single-handedly killing seventyseven people, most of them one by one, many of them eye to eye, did not take place in a wartime society, where all norms and rules were lifted and all institutions dissolved; it occurred in a small, harmonious, well-functioning, and prosperous land during peacetime. All norms and rules were annulled in him, a war culture had arisen in him, and he was completely indifferent to human life, and absolutely ruthless. That is where we should direct our attention, to the collapse within the human being which these actions represent, and which makes them possible." (Knausgaard, 2015)

For all the flaunting of anti-immigrant and anti-Muslim bigotry, Breivik's bizarre acts leading up to, during and after the massacre amount, for Knausgaard, to "roleplaying, rather than political terrorism." One may quarrel with his conclusion, which seems to assume that such role-playing is necessarily distinct from terrorism; terrorists are often intent on posturing larger-than-life roles. Yet it is surely true that the erosion of basic human constraints against acts of mass murder in peacetime and prosperity is no ordinary thing, and suggests

${ }^{6}$ Knausgaard's account draws heavily on the comprehensive narrative in Sierstad (2013). acute alienation. Knausgaard contrasts the internal collapse of constraints and instincts with their external/societal demise in situations like Iraq and Syria, and earlier in the Balkans and Rwanda. But the extraordinary brutality of Daesh, al-Qaeda, and the like is also perpetrated by recruits (and "supporters") from places of relative peace and prosperity across the world. ${ }^{7}$ In other words, by individuals who have much in common with Breivik. Daesh's behavior, Knausgaard observes, "cannot be ascribed to people having suddenly become evil but, rather, to the disintegration of the mechanisms that in a civilized society typically prevent people from engaging in rape and murder." This social disintegration, then, runs with the internal collapse of individual constraints and instincts.

Modernity's alienating structural effects on individual identity-anomie-were evident over a century ago to Emile Durkheim, and are a core concern in the social sciences (Orru, 1987). The effects are heightened by secular globalization as a vital feature of the contemporary landscape. As noted, public culture is in tension with religion not only among communities of faith, but also in the policy frameworks of modern states that "format" religious practices and institutions. It is no surprise that the ensuing challenges to identity can provoke strong responses. The "politics of resentment" finds global expression along diverse avenues (Mazar, 2014), from fierce protests over dignity and national pride to violent insurgencies on behalf of imagined precolonial identities. Narratives of humiliation, grievance and fear are a staple not only of extremist groups, but also of nationalisms and "democratic" demagogues. Receptivity to them rests on political and social alienations. For the anthropologist Scott Atran, who has interviewed youths drawn to violence on six continents-including most recently in Iraq-the alienations feed a "dynamic countercultural movement":

\begin{abstract}
"Violent extremism represents not the resurgence of traditional cultures, but their collapse, as young people unmoored from millennial traditions flail about in search of a social identity that gives personal significance and glory. This is the dark side of globalization. They radicalize to find a firm identity in a flattened world where vertical lines of communication between the generations are replaced by horizontal peer-to-peer attachments that can span the globe." (Atran, 2015)
\end{abstract}

Social bonds and sacred values are key attractions in countering modernist alienations (Atran, 2010; Atran, Hammad, \& Gomez, 2014). Groups like Daesh and alQaeda offer both: the intimacy of family-like group af-

\footnotetext{
7 The cumulative number of foreign recruits to Daesh is estimated to have doubled in the year since mid-2014, at 27,000-31,000 from 86 countries (The Economist, 2015).
} 
filiation, and a view of the shari'a as sacred (2014). Beyond providing comfort and empowerment, sacred values confer legitimacy to narratives of grievance and of heroic response against long odds. Secular causes such as nationalism and ethno-cultural pride may similarly offer legitimating narratives, along with kinshiplike support. But religious affiliations have the advantage of being inherently transnational, which allows for a greater repertoire of symbolic and social capitalwith access to the digital tools of a globalized public sphere (Bunt, 2009; Eickelman \& Anderson, 2003). Social media is not incidental to religious movements, but often a core aspect of their profiles and global reach; the gap between cyber and real communities offering social bonds and sacred values is rapidly shrinking (Bunt, 2009, pp. 291-292). Modernity's orphans are seldom averse to using its technological assets to the full.

Yet modernity's orphans are not confined to the margins of extremism or to "fundamentalist" religiosity. Anomie is a wider "malaise" (Taylor, 1991, 2007), and the responses to its secular forms are manifold. Multiple studies on both sides of the Atlantic over the past decade have found remarkably little to distinguish the demographic markers of "violent extremists" from the rest of the population (Atran, 2015; Patel, 2011; Travis, 2008). They are usually not well-schooled in religion; many are outright irreligious. Conventional family ties are common, and evidence of pathologies is no greater than for the mainstream. Although many come from lower economic strata-in western and Muslimmajority countries-there is also marked representation from the middle classes. In this vein, while most Muslims in the western diaspora feel that they belong to their countries of residence, local populations, notably in Germany and Spain, mostly believe the contrary (Benton \& Nielsen, 2013; Saunders, 2012). Pew surveys of US Muslims over several years consistently find negligible levels of sympathy, much less support, for extremism, and far higher levels of satisfaction with American life than is found in the general public (Pew Research Centre, 2011). By contrast, only 33\% of the US public believed that Muslim Americans wish to be an integral part of the nation. On the eve of Republican presidential candidate Donald Trump's call in December 2015 to exclude Muslims from entry into the US, $55 \%$ of Americans had an unfavorable view of Islam, and sentiments toward Muslims were the "coldest" of any religious community (Chalabi, 2015). Trump's proposal was supported by a majority of Republicans (43\%) and $25 \%$ of all Americans, according to an NBCWall Street Journal poll (Bradner, 2015).

Isolating violent extremists from ordinary Muslims or mainstream society, it turns out, is harder for various publics, demagogues, and social scientists than identifying the sources and symptoms of modernist angst. It is harder still in the diverse societies of the "Muslim world" - from South-Central Asia and West Africa to the
Middle East and North Africa-where fresh syntheses of Islam and modernity are in the making (Sajoo, 2008). Radicalization and violent extremism are real phenomena; yet they cast a fog over the complexity of modern social imaginaries, and hence to the nature of responses to those phenomena by states and civil societies.

\subsection{Pluralism Revisited}

In the aftermath of the 2010-11 uprisings in Tunisia, Egypt, Libya and Yemen that came to be described as "the Arab Spring," a study on youths aged 17 to 31 in 2013 yielded telling results (Al-Anani, 2015; Atassi, 2013). The new governing institutions were uniformly felt to be unrepresentative, and most had no party affiliation. Large majorities considered themselves as Muslims first, ahead of national citizenship; the exception was Egypt, where 35\% did so. Majorities in all four countries-from $91 \%$ in Libya to $57 \%$ in Egypt-favored implementing the Shari'a as national law. In Tunisia, widely regarded as the success story of the Arab Spring, only $14 \%$ felt that the revolution which toppled the authoritarian government of Zine El Dine Ben Ali was a success. Constitutional reforms have since garnered much public support, and a civil society coalition won the 2015 Nobel Peace Prize (Chan, 2015). Yet Tunisia is among the highest sources of recruits per capita to Daesh and al-Qaeda, ahead of Saudi Arabia and exceeded only by Jordan (Sengupta, 2014).

The survey results are consistent with recent trends regarding citizenship, identity and religiosity across Muslim-majority societies. In tandem with fragile rule of law and democratic governance, citizenship tends to entwine with religious identity across the Middle East, South Asia, and Sub-Saharan Africa. Enacting the shari'a as the law of the land is favored by over $70 \%$ of the population in states ranging from Afghanistan, Iraq, Jordan, Nigeria and Pakistan to Indonesia, Morocco, Malaysia and the Palestinian Territories; the only regions where firm majorities oppose this are Central Asia and Southeastern Europe (Pew Research Centre, 2015). In sub-Saharan states where Muslims are a relatively small minority, the shari'a is still desired by more than half of Muslims (52\%-74\%) as national law. Religion is felt to be a precondition for individual moral standing by a majority of Muslims in all regions (Pew Research Centre, 2013). For large majorities the shari'a is the divine word, undistinguished from the corpus of legal rules or fiqh (An-Na'im, 2008; Moustafa, 2013; Pew Research Centre, 2013). It is also understood as subject to a single interpretation by the majority, especially in South Asia and the Middle East (Pew Research Centre, 2013); strong majorities in the Muslim world also hold to a singular understanding of Islam (Pew Research Centre, 2012). ${ }^{8}$

\footnotetext{
8 Morocco and Tunisia stand out as exceptions to both claims:
} 
Perhaps not surprisingly, the very acceptance of Muslim minorities is narrow. A majority of Egyptians, Indonesians and Jordanians, who are Sunni, do not recognize the Shi'a, whose origins are anchored in the earliest years of Islamic history, as fellow Muslims (Pew Research Centre, 2012). The Ahmadiyya minority, whose orientation is Sunni, enjoys even less acceptance. Sufi communities, most of which are also Sunni in orientation and whose esotericism has long been regarded as a core facet of Islam, are today recognized as Muslim by about half of Egyptians, Tunisians and Iraqis (Pew Research Centre, 2012). PostSeptember 11 initiatives to broaden the theological fold, such as the Amman Declaration by leading Sunni and Shi'a institutional figures who affirmed an inclusive and tolerant Islam (International Islamic Conference, 2005), have since run into hardline sectarian polemic at the highest levels (Fahim, 2015). Given the level of sectarianism not only in civil conflicts in Afghanistan, Bahrain, Iraq, Lebanon, Syria, and Yemen, but more broadly in tensions across the Muslim world, the theological backdrop-how the shari'a is perceived, and how individual/communal identities are tied to particularistic interpretations of Islam-can hardly be dismissed as merely captive to politics.

Theology stirred with politics has long been a staple of al-Qaeda, despite the hollow claims to juristic competence by Osama bin Laden (Lawrence, 2005). If the leaders of Boko Haram, Daesh, al-Shabab and the Taliban are even less versed on the finer points of theology, this has not stood in the way of their claims to authenticity and orthodoxy (Burke, 2015; McCants, 2015; Nordland, 2015). Even Arabic poetic traditions are marshalled in the service of these claims (Creswell \& Haykel, 2015). And Daesh has invoked ritual, scripture and tradition, embodied in a manual, to rationalize the sexual enslavement of female children (Callimachi, 2015). This is endemic to the misogynistic attitudes that find their way into interpretations of gender in theology, far beyond the confines of "extremism" (MirHosseini, Al-Sharmani, \& Rumminger, 2015).

The conservative trends in the politics of identity that have provided such fertile ground for extremist theologies of exclusion are not confined to Muslim societies. Pew's "Social Hostilities Index," a complex measure of religiously-inspired acts of abuse/aggression by individuals and groups, has spiked-with intense majoritarian attacks against vulnerable minorities (often Muslims) in India, Myanmar, Sri Lanka, Vietnam, and China, as well as in the Middle East, Sub-Saharan Africa, and Indonesia (Pew Research Centre, 2014). For the celebrated Indian writer Arundhati Roy, "intolerance" is an utterly inadequate term to describe the "terror" that minorities such as Christians, Dalits, and Muslims

firm majorities subscribe to multiple interpretations, though in both countries majorities insist that the shari'a is divine. now experience in her country (Roy, 2015). Much the same can be said of Rohingya Muslims in Myanmar, where Buddhist "extremism reflected in the laws suggests a future of even greater violence" (Mathieson, 2015; Physicians for Human Rights, 2013). Of late, researchers in the US describe thus the vulnerability of Muslims there:

"It is not just that hatred against Muslims is extremely high today. It's that it's exceptional compared with prejudice against every other group in the United States. We examined prejudicial searches against black people, white people, gay people, Asians, Jews, Mexicans and Christians. We estimate that negative attitudes against Muslims today are higher than prejudice against any group in any month since 2004, when Google began preserving detailed data on search volumes." (Soltas \& Stephens-Davidowitz, 2015) ${ }^{9}$

Hostility toward individuals and groups on the basis of their perceived faith affiliation inevitably privileges one kind of identity-religious-over others. Likewise, the stated theological agendas of extremist organizations, no matter how shallow or manipulative, make exclusive claims on the religious identities of their recruits and victims alike. Where does this leave the multiple identities that are central to pluralist civil society, and to countering violent extremism (Sen, 2006; Maalouf, 2001)? Modernist discourse has hitherto insisted on a "secularist" basis for the former. But secularist orthodoxy collides with hard realities about the place of religion in individual and group identities. Casting civic culture and citizenship as "bulwarks against religion" does not empower secular reason so much as narrow the reach of social inclusion in diverse public spaces (Taylor, 2011, p. 56; Stepan, 2011; Nandy, 1998). A nuanced appreciation of what is "secular," beyond the reflexive antagonism toward religion that is too often found in secular orthodoxy, brings us closer to the kind of pluralist citizenship that is professed in liberal ideology (Stepan, 2011).

A wariness of theologies of exclusion, religious or secular, is entirely proper in defending pluralist civic cultures. Far from being confined to the extremist/radicalized margins, exclusionary theologies are pervasive and fuel for recruitment to the former. A conspicuous example: "mainstream" Wahhabi interpretations of the shari'a as spearheaded by Saudi Arabia's clerical and political establishments are foundational for the theologies of groups such as Daesh and al-Qaeda (Armstrong, 2014; Daoud, 2015; Matthiessen, 2015; McCants, 2015). ${ }^{10}$ That Saudi Arabia is a key

\footnotetext{
9 This is accompanied by a spike in actual hate crimes (Lichtblau, 2015). Similar trends prevail not only in Europe, but also in Australia (K. Dunn, 2015).
}

${ }^{10}$ Amid the competitive animosity between Riyadh and those 
western economic and political ally has obvious implications: a mutual interest prevails in isolating extremism/radicalization as the "real" foe (Black, 2015). In neighboring Bahrain, the "extremist" tag serves not only to fuel sectarian repression of the Shi'a majority, but to undermine democratic accountability, with Saudi Arabia playing a leading role; as noted by Human Rights Watch (HRW), among others, this is abetted by Britain and the United States (Americans for Human Rights \& Democracy in Bahrain, 2015; HRW, 2015; Ramesh, 2016). The extremist tag has also been exploited in Central Asia, where perceived Wahhabi tendencies have led to authoritarian crackdowns on any overt religiosity-as in Tajikistan, where even beards and dark clothing are suspect (Paraszczuk, 2015; Sarkorova, 2016). In an echo of the Soviet era, citizenship is construed strictly along lines of exclusive secular orthodoxy. Nor is there a dearth of such baggage today within western mainstreams, with the ascendance of the far-right and the banality of hate speech, in which religious identities are engaged willy-nilly.

Pluralisms that draw on theologies of inclusion, beyond mere accommodation or tolerance, offer the prospect of bridging modernist divides toward a richer civic identity. Scholars such as Diana Eck, Ashis Nandy and Charles Taylor have wrestled with Hindu and JudeoChristian makings of fresh cosmopolitanismsalongside Abdullahi An-Na'im, Tariq Ramadan and Omid Safi on the Muslim side-in fragmented public domains (Aga Khan, 2015a, 2015b; Karim, 2012; Marshall, 2013; Poor, 2015, pp. 152-158). To the questions "who is a Muslim" and "what is Islam," we have responses that engage fully with civic domains as well as with theology (Ahmed, 2015; An-Na'im, 2008). A fresh initiative in this regard is the Marrakesh Declaration (on Religious Minorities in Muslim-majority Countries), adopted in January 2016 by over 300 religious and political leaders from across the Muslim world (Marrakesh Conference on the Rights of Religious Minorities in Predominantly Muslim Majority Countries, 2016). In its focus on minority rights and citizenship, the Declaration calls for a vigorous Islamic jurisprudence, alongside a review of educational curricula-while invoking the inclusive spirit of the Charter of Medina drawn up by the Prophet Muhammad as a civic expression of religiosity.

Rather than transcend difference with universalist rhetoric and secular "reason," or merely enable differences to co-exist, the aspiration here is to mobilize religious affiliation as a contributor to civic ethics. The Rawlsian "overlapping consensus" is thickened, so that faith affinities cease being treated as outliers that must be privatized (Aga Khan, 2006; Taylor, 2011). Controversies over the wearing of Muslim head/face cover-

terror groups, a shared sectarian narrative directed at the Shi'a and Iran continues to serve overlapping interests (Mathieson, 2015). ings in public spaces (courts, citizenship ceremonies, public schools, et al.) point to the dominance of a thin description of inclusion, despite its exclusionary impact. Likewise, sectarian trends are a reminder of the rigidities of identity among faith traditions: distinctiveness is equated with exclusivity, pluralism with dilution. ${ }^{11}$ The queries "Who is Shi'a?" or "Who is Sunni?" or "Who is Protestant?" call for responses that are mindful of the slippage to chauvinism (Sajoo, 2015).

\section{Conclusion}

Exclusionary theologies that are fed by, and in turn reinforce, the narrowing of religious identities flourish well beyond the periphery, in Muslim and non-Muslim domains today. It is not that exclusivism, much less conservatism, simply turns into violent extremism on a "conveyor belt" of displeasure. Rather, the former validates ideologies that enable and incite extremism, including its sectarian expression. Theologies of inclusion matter because they draw on diverse heritages that are a legitimate part of a global landscape where religious identities matter. Faith traditions have long embodied a "rooted worldliness," a transnational sensibility with local commitments, as integral to their ethics. This is inconsistently nourished: religions, like secular cultures, have historic ups and downs in the generosity accorded the Other. Both require cultivation on this score, and convergence.

Yes, deficits in the quality of life, employment, equality, and accountable governance fuel disaffection that extremist violence thrives on. The Arab Spring had much to do with such disaffection, and the appeals to empowerment offered by Islamist actors (Bishara, 2013; Hamid, 2014). But neither material incentives nor military responses can obliterate extremist violence, even if they were to succeed in disposing of Daesh, al-Qaeda, and their like. Still less can they answer the challenge of exclusive identities that undermine civil society, citizenship and gender equity.

"Non, domina magna, we cannot under any circumstances." This is the response in diverse tongues of the minstrels of war when asked to sing their shared narratives, in our epigraph from Ismail Kadare's Elegy for Kosovo. The mold that holds the minstrels captive is too embedded, and the compulsion for war too robust, to let them partake in the grander narrative which they find so attractive. Kadare's lyrical account of the con-

\footnotetext{
11 In a graphic illustration, Wheaton College, a prestigious Christian evangelical institution located near Chicago, suspended a tenured professor who donned a hijab in solidarity with Muslims who "worship the same God." Her statement was deemed unacceptable on the basis that the Christian concept of God is uniquely Trinitarian and thence different from the unitarian Allah. After protests against her suspension among students and faculty, a settlement was reached for the professor to leave Wheaton (Hauser, 2016).
} 
flicts in ex-Yugoslavia may be taken as symbolic of the ethno-religious inheritance that plagues the orphans of modernity. Yet this leaves out the role of modernity's own minstrels, notably those wedded to secular ideologies that impel wars on the Other. In Miroslav Volf's striking engagement with the stakes in the Balkan conflicts, the "character of social agents and their mutual engagement" is central to a theological exploration (Volf, 1996, 2016). Social inclusion, then, is as much a religious as a secular preoccupation - which calls for a more sophisticated appreciation of what these categories stand for. When the minstrels on each side have woken from what Kadare calls their "stupor," can they afford to say "non" to a fresher pluralism? Syria, Yemen, Iraq, Afghanistan and a host of other broken societies await the response.

\section{Acknowledgements}

I am grateful to the journal's editors as well as the anonymous reviewers of this article for their thoughtful remarks on the draft version.

\section{Conflict of Interests}

The author declares no conflict of interests.

\section{References}

Abrahamian, E. (2003). The US media, Huntington, and September 11. Third World Quarterly, 24(3), 529544.

Abu-Rabi, I. (Ed.). (2010). The contemporary Arab reader on political Islam. Edmonton, Canada: University of Alberta Press.

Aga Khan, K. (2006, February 12). Symposium on "Cosmopolitan Society, Human Safety and Rights in Plural and Peaceful Societies". Évora University, Portugal. Retrieved from http://www.akdn.org/Content/228/ Evora-University-Symposium

Aga Khan, K. (2015a, November 12). The cosmopolitan ethic in a fragmented world. Weatherhead Center for International Affairs. Retrieved from http://wcfia. harvard.edu/jodidi/2015/transcript-aga-khan

Aga Khan, K. (2015b, November 12). A conversation between His Highness the Aga Khan and Professor Diana L. Eck. Weatherhead Center for International Affairs. Retrieved from http://wcfia.harvard.edu/ lectureships/jodidi/2015/transcript_AgaKhan-DEck

Ahmed, S. (2015). What is Islam? The importance of being Islamic. Princeton, NJ: Princeton University Press.

Al-Anani, K. (2015). Inside the Muslim brotherhood: Religion, identity and politics. Oxford: Oxford University Press.

Americans for Human Rights \& Democracy in Bahrain. (2015). Shattering the facade: A report on Bahrain's implementation of the Bahrain Independent Commis- sion of Inquiry (BICl) four years on. Retrieved from http://ADHRB_BICl_Web-rev2-2

An-Na'im, A.A. (2008). Islam and the Secular State: Negotiating the Future of Shari'a. Oxford: Oxford University Press.

Armstrong, K. (2014, November 27). Wahhabism to ISIS. The New Statesman. Retrieved from http://www. newstatesman.com/world-affairs/2014/11/wahhab ism-isis-how-saudi-arabia-exported-main-sourceglobal-terrorism

Atassi, B. (2013, July 29). Poll: Arab youth feel alienated from politics. Aljazeera. Retrieved from http:// www.aljazeera.com/news/middleeast/2013/07/201 3729103126233170.html

Atran, S. (2010). Talking to the enemy: Faith, brotherhood, and the (un)making of terrorists. New York: HarperCollins.

Atran, S. (2015). Here's what the social science says about countering violent extremism. Huffington Post. Retrieved from http://www.huffingtonpost.com/ scott-atran/violent-extremism-socialscience_b_7142604.html?utm_hp_ref=Science

Atran, S., Hammad, S., \& Gomez, A. (2014). Devoted actors sacrifice for close comrades and sacred cause. Proceedings of the National Academy of Sciences, 111(50), 17702-17703. Retrieved from http://www. pnas.org/content/111/50/17702.full

Bawer, B. (2006). While Europe slept: How radical Islam is destroying the West from within. New York: Doubleday.

Bawer, B. (2009). Surrender: Appeasing Islam, sacrificing freedom. New York: Random House.

Bayat, A. (2013). Post-Islamism: The changing faces of political Islam. Oxford: Oxford University Press.

Benton, M., \& Nielsen, A. (2013, May 10). Integrating Europe's Muslim minorities: Public Anxieties, policy responses. Migration Information Source. Retrieved from http://www.migrationpolicy.org/article/integra ting-europes-muslim-minorities-public-anxietiespolicy-responses

Berger, P. (Ed). (1999). The desecularization of the world: Resurgent religion and world politics. Grand Rapids, MI: Erdmans.

Bhargava, R. (Ed.). (1998). Secularism and its critics. Oxford: Oxford University Press.

Bishara, M. (2013). The invisible Arab: The promise and perils of the Arab revolutions. New York: Nation Books.

Black, I. (2015, December 15). "Saudi Arabia's antiterrorism alliance: A political message sketchy on details. The Guardian. Retrieved from http://www. theguardian.com/world/2015/dec/15/saudi-arabiaanti-terrorism-alliance-political-message-sketchydetails?CMP=share_btn_fb

Bouma, G. (2008). The challenge of religious revitalization and religious diversity to social cohesion in secular societies. In B. Turner (Ed), Religious diversity and 
civil society (pp. 13-25). Oxford: The Bardwell Press.

Bradner, E. (2015, December 10). GOP primary voters split over Trump's Muslim ban, poll finds. CNN Politics. Retrieved from http://www.cnn.com/2015/12/ 10/politics/donald-trump-muslims-poll/index.html

Breivik, A. (2011, July, 22). 2083: A European declaration of independence. Archives.org. Retrieved from https://archive.org/details/2083_A_European_Decla ration_of_Independence

Bunt, G. (2009). The digital umma. In A. B. Sajoo (Ed.), A companion to the Muslim world (pp. 291-310). London: I.B. Tauris.

Burke, J. (2015, September). The truth about the caliphate. Prospect. Retrieved from http://www. prospectmagazine.co.uk/features/state-of-terror

Callimachi, R. (2015, August 14). Enslaving young girls, the Islamic state builds a vast system of rape. New York Times, p. A1.

Castellino, J., \& Cavanaugh, K. (2013). Minority rights in the Middle East. Oxford: Oxford University Press.

Chalabi, M. (2015, December 8). How anti-Muslim are Americans? Data points to extent of Islamophobia. The Guardian. Retrieved from http://www.the guardian.com/us-news/2015/dec/08/muslims-usislam-islamophobia-data-polls

Chan, S. (2015, October 10). Peace prize goes to Tunisian group for backing democracy after Arab Spring. New York Times, p. A6.

Creswell, R., \& Haykel, B. (2015, June 8). Battle lines: Want to understand the jihadis? Read their poetry. The New Yorker. Retrieved from http://www.new yorker.com/magazine/2015/06/08/battle-lines-jihad -creswell-and-haykel

Cumming-Bruce, N., \& Erlanger, S. (2009, November 30). Swiss ban building of minarets on mosques. New York Times, p. A6.

Daoud, K. (2015, November 20). Saudi Arabia, an ISIS that has made it. New York Times. Retrieved from http://www.nytimes.com/2015/11/21/opinion/saudi -arabia-an-isis-that-has-made-it.html?_ $r=0$

Dunn, K. (2015). The resilience and ordinariness of Australian Muslims: Attitudes and experiences of Muslims report. Sydney: Western Sydney UniversityIslamic Sciences \& Research Academy Australia. Retrieved from www.uws.edu.au/_data/.../12441_ text_challenging_racism_WEB.pdf

Dunn, M. (2006). The 'Clash of Civilizations' and the 'War on Terror'. $49^{\text {th }}$ Parallel, 20, 1-20.

Eickelman, D., \& Anderson, J. (Eds.). (2003). New media in the Muslim world: The emerging public sphere (2nd ed.). Bloomington, IN: Indiana University Press.

Fahim, K. (2015, October 18). Sectarian leaders fan flames in Middle East. New York Times, p. A14.

Ferguson, N. (2004, April 4). “Eurabia?" New York Times Magazine. Retrieved from http://www.nytimes.com/ 2004/04/04/magazine/04WWLN.html

Ferguson, N. (2006, May 21). The march of Islam. The
Telegraph. Retrieved from http://www.telegraph.co. uk/culture/3652572/The-march-of-Islam.html

Ferguson, N. (2011). Civilization: The West and the rest. London: Allen Lane.

Grayling, A. C. (2016, January). Daesh: It is not Islamic, or a state and this isn't a war. Prospect. Retrieved from http://www.prospectmagazine.co.uk/opinions/thepower-of-words-daesh-islamic-state-iraq-syriaterrorism

Hamid, S. (2014). Temptations of power: Islamists and illiberal democracy in a new Middle East. New York: Oxford University Press.

Harris, S. (2004). The end of faith: Religion, terror, and the future of reason. New York: W.W. Norton.

Hassan v. The City of New York. (2015, October 13). United States Court of Appeals, Third Circuit. Case No. 14-1688. Retrieved from http://www2.ca3. uscourts.gov/opinarch/141688p.pdf

Hauser, C. (2016, February 8). Wheaton College and Professor to 'part ways' after her remarks on Muslims. New York Times. Retrieved from http://www.ny times.com/2016/02/09/us/larycia-hawkins-wheatoncollege.html?_r=0

Hedges, C. (2008). When Atheism becomes religion: America's new fundamentalists. New York: Free Press.

Human Rights Watch. (2015). The blood of people who don't co-operate: Continuing torture and mistreatment of detainees in Bahrain. Retrieved from https://www.hrw.org/node/283352

Huntington, S. P. (1996). The clash of civilizations and the remaking of world order. New York: Simon \& Schuster.

International Islamic Conference. (2015, July 4-5). Amman Declaration: Statement issued by the Internation Islamic Conference. Amman, Jordan. Retrieved from http://ammanmessage.com/index.php?option $=$ com_content\&task=view\&id=20\&/temid $=34$

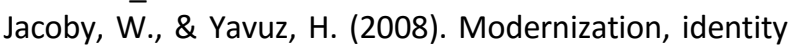
and integration: An introduction to the special issue on Islam in Europe. Journal of Muslim Minority Affairs, 28(1), 1-6.

Juergensmeyer, M. (2003). Terror in the mind of God: The global rise of religious violence. Berkeley, CA: University of California Press.

Juergensmeyer, M., Griego, D., \& Soboslai, J. (2015). God in the tumult of the global square: Religion in global civil society. Oakland, CA: University of California Press.

Kadare, I. (1998). Elegy for Kosovo. New York: Arcade Publishing.

Karim, K. (2012). Cosmopolitanism: Ways of being Mus$\lim$. In A. Sajoo (Ed.), A companion to Muslim cultures (pp. 201-220). London: I.B. Tauris.

Kettell, S. (2013). Faithless: The politics of new atheism. Secularism and Nonreligion, 2, 61-78. Retrieved from http://www.secularismandnonreligion.org/articles/1 


\section{$0.5334 /$ snr.al}

Knausgaard, K. (2015, May 25). The inexplicable: Inside the mind of a mass killer. The New Yorker. Retrieved from http://www.newyorker.com/magazine/2015/ 05/25/the-inexplicable

Kymlicka, W. (2001). Politics in the vernacular: Nationalism, multiculturalism, and citizenship. Oxford: Oxford University Press.

Kymlicka, W., \& Norman, W. (Eds.). (2000). Citizenship in diverse societies. Oxford: Oxford University Press.

Lawrence, B. (2005). Messages to the world: The statements of Osama Bin Laden. London \& New York: Verso.

Lewis, B. (1990). "The Roots of Muslim Rage." The Atlantic Monthly. 266: 3, pp. 47 - 60.

Lewis, B. (2002). What went wrong: The clash between Islam and modernity in the Middle East. New York: Oxford University Press.

Lewis, B. (2003). The crisis of Islam: Holy War and unholy terror. New York: Random House.

Lichtblau, E. (2015, December 18). Crimes against Muslim Americans and mosques rise sharply. New York Times, p. A26.

Littman, G. (2005). Eurabia: The Euro-Arab axis. Madison, NJ: Fairleigh Dickinson University Press.

Lyon, D. (2015). Surveillance after Snowden. Cambridge, UK: Polity.

Maalouf, A. (2001). In the name of identity: Violence and the need to belong. New York: Arcade.

Marrakesh Conference on the Rights of Religious Minorities in Predominantly Muslim Majority Countries. (2016, January 25-27). Retrieved from http://www. marrakeshdeclaration.org/index.html

Marshall, K. (2013). Global institutions of religion: Ancient movers, modern shakers. London: Routledge.

Martin, D. (2005). On secularization: A revised general theory. Aldershot, UK: Ashgate.

Martin, R., \& Barzegar, A. (Eds.). (2010). Islamism: Contested perspectives on political Islam. Redwood City, CA: Stanford University Press.

Mathieson, D. S. (2015, June 16). Religious extremism looms over Myanmar. New York: Human Rights Watch. Retrieved from https://www.hrw.org/news/ 2015/06/16/religious-extremism-looms-overmyanmar

Matthiesen, T. (2015, August). The domestic sources of Saudi foreign policy: Islamists and the state in the wake of the Arab Uprisings. In rethinking political Islam series. New York: Brookings. Retrieved from http://www.brookings.edu/research/reports2/2015/ 08/ /media/371341741F72445E8269110C5504E327 .ashx

Mazar, M. J. (2014, July 3). The age of grievance. Foreign Affairs. Retrieved from https://www.foreignaffairs. com/articles/russian-federation/2014-07-03/age-grie vance?cid=nlc-foreign_affairs_this_week-071014-the _age_of_grievance_5-
071014\&sp_mid=46430687\&sp_rid=YW15bl9zYWpv bOBob3RtYWIsLmNvbQS2

McCants, W. (2015). The ISIS apocalypse: The history, strategy and doomsday vision of the Islamic State. New York: St. Martin's Press.

Mir-Hosseini, Z., Al-Sharmani, M., \& Rumminger, J. (Eds.). (2015). Men in charge? Rethinking authority in Muslim legal tradition. Oxford: Oneworld.

Modood, T. (2000). Anti-essentialism, multiculturalism, and the 'recognition' of religious groups. In W. Kymlicka \& W. Norman (Eds.), Citizenship in diverse societies (pp. 175-195). Oxford: Oxford University Press.

Moustafa, T. (2013). Islamic law, women's rights, and popular legal consciousness in Malaysia. Law \& Social Inquiry, 38(1), 168-188.

Nandy. A. (1998). The politics of secularism and the recovery of religious tolerance. In R. Bhargava (Ed.), Secularism and its critics (pp. 321-379). New Delhi: Oxford University Press.

Neumayer, E., \& Plumper, T. (2009). International terror and the clash of civilizations. British Journal of Politics, 39, 711-734.

Nordland, R. (2015, December 17). Dealing a blow to extremists but not ideology. New York Times, p. A16.

Orru, M. (1987). Anomie: History and meanings. Boston: Allen \& Unwin.

Paraszczuk, J. (2015, October 29). Tajikistan's crackdown on Islam 'helps IS recruiters'. Radio Free Europe. Retrieved from http://www.rferl.org/content/tajikistan -crackdown-helping-islamic-state-recruiting/2733385 9.html

Patel, F. (2011). Rethinking radicalization. New York: Brennan Centre for Justice, New York University School of Law. Retrieved from https://www.brennan center.org/sites/default/files/legacy/RethinkingRadi calization.pdf

Pew Research Centre. (2011, August 30). Muslim Americans: Mainstream and moderate attitudes. Washington, DC: Pew Charitable Trusts. Retrieved from http://www.people-press.org/2011/08/30/muslimamericans-no-signs-of-growth-in-alienation-orsupport-for-extremism

Pew Research Centre. (2012, August 9). The world's Muslims: Unity and diversity. Washington, DC: Pew Charitable Trusts. Retrieved from http://www.pew forum.org/files/2012/08/the-worlds-muslims-fullreport.pdf

Pew Research Centre. (2013, April 30). The World's Muslims: Religion, politics and society. Washington, DC: Pew Charitable Trusts. Retrieved from http://www. pewforum.org/2013/04/30/the-worlds-muslimsreligion-politics-society-overview

Pew Research Centre. (2014, January 14). Religious hostilities reach six-year high. Washington, DC: Pew Charitable Trusts. Retrieved from http://www.pew forum.org/2014/01/14/religious-hostilities-reach-six- 
year-high

Pew Research Centre. (2015, December 7). Muslims and Islam: Key findings in the U.S. and around the world. Washington, DC: Pew Charitable Trusts. Retrieved from http://www.pewresearch.org/fact-tank/2015/ 12/07/muslims-and-islam-key-findings-in-the-u-sand-around-the-world

Pföstl, E., \& Kymlicka, W. (2015). Minority politics in the Middle East and North Africa: The prospects for transformative change. Ethnic and Racial Studies, 38(14), 2489-2498.

Physicians for Human Rights. (2013, May). Massacre in Central Burma. Cambridge, MA. Retrieved from https://s3.amazonaws.com/PHR_Reports/BurmaMeiktila-Massacre-Report-May-2013.pdf

Pipes, D. (2002a). Militant Islam reaches America. New York: W.W. Norton.

Pipes, D. (2002b). Faces of American Islam. Daniel Pipes: Middle East Forum. Retrieved from http://www. danielpipes.org/441/faces-of-american-islam-muslim -immigration

Pizzo, P. (2015). The 'coptic question' in postrevolutionary Egypt: Citizenship, democracy, religion. Ethnic and Racial Studies, 38(14), 2598-2613.

Poor, D. M. (2015). Authority without territory: The Aga Khan Development Network and the Ismaili imamate. New York: Palgrave Macmillan.

Ramesh, R. (2016, February 9). Bahrain's UK-funded police watchdog fails to investigate torture claims. The Guardian. Retrieved at http://www.theguardian. com/world/2016/feb/09/bahrains-uk-funded-policewatchdog-fails-to-investigate-torture-claimsmohammed-ramadan?CMP=share btn fb

Roy, O. (2010). Holy ignorance: When religion and culture part ways. New York: Columbia University Press.

Roy, A. (2015, November 5). Why I am returning my award. The Indian Express. Retrieved from http:// indianexpress.com/article/opinion/columns/why-iam-returning-my-award

Ruse, M. (2010). Science and spirituality: Making room for faith in the age of science. New York: Cambridge University Press.

Said, E. (1994). Orientalism (25 $5^{\text {th }}$ anniversary edition). New York: Vintage Books.

Said, E. (1997). Covering Islam: How the media and the experts determine how we see the rest of the world. New York: Vintage Books.

Said, E. (2001, October, 4). The clash of ignorance. The Nation. Retrieved from http://www.thenation.com/ article/clash-ignorance

Sajoo, A. B. (Ed.). (2008). Muslim modernities: Expressions of the civil imagination. London: I.B. Tauris.

Sajoo, A. B. (2014). Review: Minority rights in the Middle East. Ethics and Global Politics, 7(1), 41-45.

Sajoo, A. B. (2015). Modernity: The ethics of identity. In F. Daftary, S. Jiwa, \& A. Sajoo (Eds.), The Shi'i World: Pathways in tradition and modernity (pp. 349-370).
London: I.B. Tauris.

Santillana, D. (1926). Istituzioni di diritto musulmano Malichita con riguardo anche al sistema Scifiita (Vol. 1, p. 5).

Sarkorova, A. (2016, January 21). Tajikistan's battle against beards to 'fight radicalisation'. BBC News. Retrieved from http://www.bbc.com/news/world-asia35372754

Saunders, D. (2012). The myth of the Muslim tide: Do immigrants threaten the west? New York: Random House.

Schofield, H. (2015, November 16). Paris attacks: 'France will destroy $I S^{\prime}-$ Hollande. $B B C$. Retrieved from http://www.bbc.com/news/world-europe-34836439

Schwanitz, S. (2004, July 28). Europa wird am Ende des Jahrhunderts islamisch sein. Die Welt.

Sen, A. (2006). Identity and violence: The illusion of destiny. London: W.W. Norton.

Sengupta, S. (2014, September 13). Nations working to stop citizens from aiding ISIS. New York Times, p. A1.

Sierstad, A. (2013). One of us. New York: Farrar, Strauss and Giroux.

Soltas, E., \& Stephens-Davidowitz, S. (2015, December 13). The rise of hate search. New York Times, p. SR1.

Spencer, R. (2008). Stealth Jihad: How radical Islam is subverting America without guns or bombs. Washington, DC: Regnery.

Spencer, R. (2009). The complete infidel's guide to the Koran. Washington, DC: Regnery Publishing.

Stepan, A. (2011). The multiple secularisms of modern democratic and non-democratic regimes. In C. Calhoun, M. Juergensmeyer, \& J. VanAntwerpen (Eds.), Rethinking secularism (pp. 114-144). New York: Oxford University Press.

Stephan, M. J. (Ed.). (2009). Civilian Jihad: Nonviolent struggle, democratization, and governance in the Middle East. New York: Palgrave Macmillan.

Steyn, M. (2006). America alone: The end of the world as we know it. Washington, DC: Regnery Publishing.

Taylor, C. (1991). The malaise of modernity. Toronto: House of Anansi Press.

Taylor, C. (2007). A secular age. Cambridge, MA: Harvard University Press.

Taylor, C. (2011). Why we need a radical redefinition of secularism. In J. Butler, J. Habermas, C. Taylor, \& C. West (Eds.), The power of religion in the public sphere (pp. 34-59). New York: Columbia University Press.

Taylor, J. (2013, April 12). Atheists Richard Dawkins, Christopher Hitchens and Sam Harris face Islamophobia backlash. The Independent. Retrieved from http://www.independent.co.uk/news/uk/homenews/atheists-richard-dawkins-christopher-hitchensand-sam-harris-face-islamophobia-backlash8570580.html

The Economist. (2006, June 26). Tales from Eurabia. p. 11. 
The Economist. (2015, December, 12). Islamic State: Unfriended. The Economist. Retrieved from http:// www.economist.com/news/middle-east-and-africa/ 21679805-there-are-signs-islamic-states-propaganda -machine-losing-its?cid1=cust/ednew/n/bl/n/201512 10n/owned/n/n/nwl/n/n/n/n

The Economist-Prospero. (2015, November, 19). The war metaphor. The Economist. Retrieved from http://www.economist.com/blogs/prospero/2015/1 1/johnson-fighting-words

Townsend, M., \& Traynor, I. (2011, July 30). Norway attacks: How far right views created Anders Behring Breivik. The Guardian. Retrieved from http://www. theguardian.com/world/2011/jul/30/norway-attacks -anders-behring-breivik

Travis, A. (2008, August 21). MI5 report challenges views on terrorism in Britain. The Guardian. Retrieved from http://www.theguardian.com/uk/2008/aug/20/ukse curity.terrorism 1

UK Government. (2014). Home Secretary Theresa May on Counter Terrorism. Retrieved from https://www. gov.uk/government/speeches/home-secretarytheresa-may-on-counter-terrorism

Volf, M. (1996). Exclusion and embrace: A theological exploration of identity, otherness, and reconciliation. Nashville, TN: Abingdon Press.

Volf, M. (2016). Flourishing: Why we need religion in a globalized world. New Haven, CN: Yale University Press.

Wilson, E. K. (2012). After secularism: Rethinking religion in global affairs. New York: Palgrave Macmillan.

Wright, R. (2015, February 25). The clash of civilizations that isn't. The New Yorker. Retrieved from http://www.newyorker.com/news/news-desk/clashcivilizations-isnt

Wright, M., Johnston, R., Citrin, J., \& Soroka, S. (2016). Multiculturalism and Muslim accommodation: Policies and predisposition in three political contexts. Comparative Political Studies, forthcoming.

Zubaida, S. (2011). Beyond Islam: A new understanding of the Middle East. London: I.B. Tauris.

\section{About the Author}

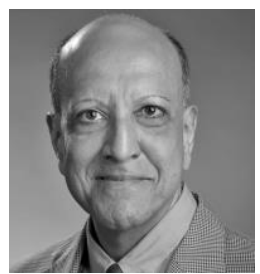

Dr. Amyn B. Sajoo

Amyn B. Sajoo lectures in global politics and history at Simon Fraser University in Vancouver, where his research is at the interface of law, ethics, and religion. He was the 2010 Canada Department of Foreign Affairs Visiting Academic in the Middle East, and is the editor of the Muslim Heritage Series (I.B. Tauris, UK). Dr. Sajoo is the author/editor of numerous books, including most recently The Shi'i World: Pathways in Tradition and Modernity (co-edited with F. Daftary \& S. Jiwa). 